\title{
Protection of Road Children's Rights in Education According to National Law
}

\author{
Heriyah $^{1}$, Megawati Barthos ${ }^{2}$ \\ University of Borobudur ${ }^{1,2}$ \\ \{heriyahunbor@gmail.com¹, megawati_barthos@borobudur.ac.id²
}

\begin{abstract}
The phenomenon of street children has become part of the face of cities in Indonesia. The issue of education for street children has long been an unfinished struggle. The emergence of a pandemic has made more unemployed and children drop out of school. It is not surprising that at the intersection of the main road, there was an increase in the school-aged street singers. There are various reasons for the reasons ranging from the absence of infrastructure tools for studying online to choosing to help parents earn a living because their life struggles must be sustained. Various parties who are responsible for children's education must work together to generate motivation for children to learn and also provide opportunities for them to study. This research describes the form and qualifications of violations of children's human rights in education. as well as efforts and protection of the human rights of street children in the field of education. The method used in this research study is the normative juridical method. Data collection was carried out by reviewing national legislation relating to children's human rights in the field of education. The research results show that the form of street children's human rights violations in the field of education is an act of neglect by the government and is included in the category of violence by omission which can be legally accountable to the government as accountability in the field of law. It is necessary Data collection was carried out by reviewing national legislation relating to children's human rights in the field of education. The research results show that the form of street children's human rights violations in the field of education is an act of neglect by the government and is included in the category of violence by omission which can be legally accountable to the government as accountability in the field of law. It is necessary Data collection was carried out by reviewing national legislation relating to children's human rights in the field of education. The research results show that the form of street children's human rights violations in the field of education is an act of neglect by the government and is included in the category of violence by omission which can be legally accountable to the government as accountability in the field of law. It is necessary the legal provisions for the protection of the rights of street children which regulate the protection of the value of the survival of development, maintenance, health, education, physical health, social moral and mental and spiritual.
\end{abstract}

Keywords: Street Children; Human Rights; Education 


\section{Introduction}

Children are a gift from God which is considered as the most valuable asset so that they are guarded and protected because they are inherent in their dignity, dignity, and highly respected human rights [1]. RA Koesnoen said that children as young people, namely young in age, young in spirit and life experience, are easily affected by their surroundings [2]. Therefore children need guidance from more mature people who can direct and provide protection. Protection of children's rights has been stipulated in the 1979 Declaration of the Child which was later adopted by the United Nations as the 1989 Convention on the Rights of the Child in Geneva and has been ratified, approved, or signed by 192 countries [3]. The issue of the convention has resulted in a conscientious commitment to give top priority to children's rights, survival, child protection, and development, including children's education.

Education is defined as a conscious and planned effort to create an atmosphere of learning and the learning process for students to actively develop their potential to have religiousspiritual strength, self-control, personality, intelligence, noble character, and skills needed by themselves and society are needed by every individual. . The importance of education for the future of individuals places the position of education as an urgent part and must be lived from childhood. The function of education aims to eliminate all sources of people's suffering, namely ignorance, and backwardness [4]. This paradigm shows that education brings hope for underprivileged children including street children to have a better future than what is currently being lived.

\section{Methodology}

The method used in this research study is the normative juridical method. Data collection was carried out by reviewing national legislation relating to children's human rights in the field of education. Data analysis is disclosed descriptively so that readers can closely understand the phenomenon being studied. Next, conclude from the results of the analysis presented and presented.

\section{Result and Discussion}

\subsection{The Phenomenon of Street Children in Indonesia}

Being a street child is not a life choice that anyone wants, but a compulsion that must be accepted because of certain causes. Street children have become a phenomenon that demands the attention of all parties. Psychologically they are children who at some level do not have a strong mental-emotional formation, while at the same time they have to deal with the world of harsh streets and tend to be negative for the formation of children's personality [5]. According to de Moura, street children can be divided into two groups, namely children who work on the streets and children who live on the streets [6]. Based on a survey conducted by the Ministry of Women's Empowerment, the reason children work is because they help with their parents' work $(71 \%)$, are forced to help their parents $(6 \%)$, add school fees $(15 \%)$, and because they want to live freely, for pocket money, get friends, and others (33\%) [7]. 


\subsection{Concept of Human Rights (HAM)}

Historically, the emergence of Human Rights (HAM) is a process of defending the community for arbitrary actions carried out by the state and also because of the imbalance between the state and society's position. The state has always been a strong party because it has authority and power while the people are in a weak position or weakened because they do not have any authority, let alone power. The authority and power inherent in the state have led to the position of the state as the bearer of the obligations [8]. The concept of human rights has a very broad meaning because human rights issues are universal, do not recognize state boundaries, political, economic, social, cultural, and legal conditions. The Law Number 39 of 1999 concerning Human Rights and Law Number 26 of 2000 concerning Human Rights Courts, each in Article 1 point 1 the concept of human rights is formulated, namely, Human rights are a set of rights inherent in the nature and existence of humans as God's creatures. The Almighty and it is His gift that must be respected, upheld, and protected by the state, law, government, and everyone for the honor and protection of human dignity [9].

Human rights have a holistic concept because the material they regulate includes economic, social, and cultural rights, individual and collective rights, and rights in the national (national) state and rights in the international system, apart from civil rights and politics [10]. The concept of human rights is divided into four views as follows [11]:

a. Absolute universal view: seeing human rights as universal values. Those with this view reject differences in tradition, culture, and religion in enforcing international human rights.

b. Relative universal view: argues that human rights remain universal but recognizes that there will be certain exceptions under the provisions stipulated in Article 29 of the World Charter of Human Rights.

c. Absolute particularistic view: seeing human rights as the problem of each nation without giving strong reasons, especially in rejecting international documents.

d. Relative particularistic view, they see human rights as not only a universal problem but also a problem of each country.

\subsection{National Law Study on the Right to Education for Children}

Efforts to protect the law for children can be interpreted as efforts to protect the law against various freedoms and human rights of children (fundamental rights and freedoms of children) as well as various interests related to the welfare of children [12]. The study of the issue of legal protection for children covers a very broad scope. Education is one of the coverage parts of children's needs that need to be protected.

In Indonesia, the global movement towards attention and enhancement of children's rights has been included in the 3rd amendment to the 1945 Constitution of the Republic of Indonesia. Several articles which become the constitutional basis of the need to pay attention to and increase children's rights, as stipulated in Article 34 paragraph (1), Article 4 of the Law No.6 of 1974, Articles 11.12 and 13 of Law Number 4 of 1979, Articles $55-58$ of Law Number 23 of 2002 and Government Regulation Number 2 of 1999 which gave the Minister of Social Affairs eight powers to carry out social welfare efforts for children. Some of these provisions clearly show how important it is to pay attention to and increase children's rights to always be fought for because it has become a constitutional right and a movement of the international community. Despite this in reality,

Street children as a part of Indonesian citizens have the right to obtain legal protection through national legal instruments. Such is the urgency of education for children, so in 1990 
the world declared education for all which in principle includes, among others: To meet the basic learning needs of all people need more than just a re-commitment to basic education while building the best things in practice which is now there; Universalizing access and promoting equality in basic education should be provided for all children, adolescents, and adults; Focusing on providing learning opportunities in the context of developing useful knowledge, skills and values; Expanding the facilities and coverage of basic education, including learning that starts at birth.

Equitable education cannot be achieved unless the education system places an inclusive education program for all children who learn either through formal or non-formal channels. In essence, the state's responsibility to establish such cooperation can only be realized if someone does. This means that as an abstract legal entity, the state cannot carry out its duties and authorities. The state is represented by the government apparatus to exercise rights and obligations. The protection of children's rights must indeed be recognized by all national and international elements. The United Nations has long recognized the right to education of children through the Universal Declaration of Human Rights (DUHAM) and the 1989 convention on children's rights. Apart from these provisions, this convention regulates children's rights regardless of race, ethnicity, religion, gender, origin, and language. Children have four basic rights, namely:

a. The right to development includes the right to education, information, free time, artistic and cultural creation, as well as human rights for children with disabilities, where they are entitled to special treatment and education.

b. The right to survival includes the right to an adequate standard of living and health services. This means that children have the right to good nutrition, proper housing, and good health care if they fall ill.

c. The right to participate includes the right to freedom of expression, association, and assembly, and participation in decision-making concerning oneself.

d. Protection rights, including protection from all forms of exploitation, cruel and arbitrary treatment in the criminal justice process, and other matters. For example, the exploitation of children through employing minors who can interfere with their learning activities.

Several national laws and regulations that regulate children's education rights can be seen in Article $28 \mathrm{C}$ paragraph (1), and Article $28 \mathrm{E}$ of the 1945 Constitution of the Republic of Indonesia. Likewise, in Article 9 paragraph (1) of Law Number 23 In 2002 concerning Child Protection (UUPA), it was stated that every child has the right to education and teaching in the context of personal development and the level of intelligence according to their interests and talents. This article is the absolute basis for the fulfillment of the child's education rights, as well as in the third part, Article 48 of the UUPA clearly states that the government is obliged to provide basic education of at least 9 (nine) years for all children, as well as Article 49 which states that the state, government, family, and parents are obliged to provide the widest possible opportunity for children to obtain an education.

This regulation clearly shows that the state regulates the rights of children, including street children, to obtain an education without having to see whether the education in question must be obtained through formal or non-formal channels and is a shared responsibility between the government, society, and the family. This provision is further clarified in Article 50 which states that children's education should not be limited to formal academic education but includes mental and spiritual education in all fields so that they are ready to face a future full of global competition. Article 50 states that education as referred to in Article 48 is directed at: a. Development of attitudes and abilities of children's personalities, talents, mental and physical abilities until they reach their optimal potential; 
b. Development of respect for human rights and fundamental freedoms;

c. Development of respect for parents, cultural identity, language, and own values, national values where the child lives, where the child comes from, and the different civilizations of one's civilization;

d. Preparation of children for responsible lives;

e. Development of respect and love for the environment.

Based on these stipulations, it can be understood that the absence of legal efforts and protection for the human rights of street children in the field of education can be juridically accounted for by the government. Recognized in several national legal instruments, this form of juridical accountability is still influenced by the paradigm of thinking about the concept of upholding social, economic, and cultural rights. The non-innovative nature of provisions in the field of education in Indonesia means that negligent education managers cannot be held accountable for their implementation. Therefore, it is time for the paradigm of law enforcement and protection of children's rights.

\subsection{Efforts and Protection of Street Children Human Rights in the Education Sector}

The implementation of child protection is an obligation and responsibility of the state, government, community, family, and parents which includes protection in the fields of religion, education, health, and society. The quality of protection for children should have a degree or level that is at least the same as that of adults because everyone has the same position. The placement of government obligations, in this case, is part of the effort to uphold rights related to economic and social rights only, but it is emphasized the same as the strengthening of civil and political rights. That is, Every street child has the right to get their basic rights in the field of education so that through education at every level street children will be fostered as part of respect for universal human rights. However, as long as this has not been implemented, the government can be seen as having committed violations of human rights, especially the human rights of street children which have resulted in a deterioration in the quality of education of the nation's children as mandated by the State's constitution.

Violations of children's rights, including the rights of street children, should have been accounted for by the government, not only politically, morally, but also legally. The theoretical foundation that can be used to reconstruct the accountability of the government for violations of the human rights of street children in the field of basic education can be realized in three forms, namely [13]:

a. Violence by Action, which occurs due to an act or action of a person or group of people, whether intentional or not.

b. Violence by Omission occurs because a person/group of people allows a human rights violation or crime or a criminal act/violation of the law.

c. Violation of human rights in terms of the substance of statutory regulations (Legislative Violence). This type of violation refers to the substance of the law which does not contain human rights principles.

In reality, the existence of street children in all their forms and roles is an act of neglect by the government and is included in the category of violence by omission which can be legally accountable to the government. It is because allowing them to roam the streets will automatically abandon their rights to receive an education. The neglect of these rights should be the duty and obligation of the government. Therefore, the government is obliged to set them in order and return them to school or place them in a social institution that allows them to get rights only in the field of education. 
For a nation, the figure of a child is very important, especially as a generation that would continue the nation's leadership in the future. Therefore, the development of children with their basic rights in the field of education must be given proper attention and treatment, considering that they are the ones who will reflect the character and existence of a nation's life in the future. Concerning the existence of these children, there are many problems faced by the nation, both regarding the mental issues of the child itself, problems that occur in sociocultural and economic relations in the family environment, which essentially, the issue of children's human rights is not only an issue of education but is closely related to economic problems of the family. The number of children who become street children is generally driven by economic factors, broken homes, loss of attention and affection of parents, and the influence of their social environment.

\section{Conclusion}

Education as the right and need of every child needs to be held accountable by the government. National legal instruments regulating children's rights in the field of education are already very strong, but their implementation in Indonesia concerning protecting the rights of street children has not been optimal. Not optimal legal protection is due to the legal provisions in the education sector which do not contain imperative legal norms which form the basis of juridical responsibility if education providers are negligent in carrying out their obligations. Furthermore, it is necessary to change the paradigm of the concept of grouping human rights in education, namely not following the concept of human rights which includes the right to education in the group of economic rights. Social and Cultural Rights (nonderogable rights) but included in the Civil Rights and Political Rights group so that the government can be brought to court (derogable rights) as a form of juridical responsibility if proven negligent in terms of managing the education sector. The provision of children's education is the obligation and responsibility of the state, government, community, family, and parents. It is necessary the legal provisions for the protection of the rights of street children which regulate the protection of the value of the survival of development, maintenance, health, education, physical health, social moral and mental and spiritual.

\section{References}

[1] LMR and RA Sumiadi, "Restorative Justice Judges Against Children in Conflict with the Law at the Lhokseumawe District Court," J. Mimb. Huk., vol. 29, no. 1, pp. 43-53, 2017.

[2] Prima Astari, "The Philosophical Foundation of Police Discretionary Actions Against Children in Confrontation with the Law," J. Arena Huk., vol. 8, no. 1, pp. 1-18, 2015.

[3] Habib Shulton Asnawi, "The Political Law of the Constitutional Court Decision No. 46 / PUU-VIII / 2010 Regarding the Status of Children Out of Marriage: Efforts to Dismantle Legal Positivism Towards the Protection of Human Rights, "J. Constitution, vol. 10, no. 2, pp. 239-260, 2013.

[4] A. Muhammad and T. Sofyan, "Legal Provisions for the Protection of Street Children in the Education Sector," J. Shari'ah and Huk. Dictum, vol. 15, no. 2, pp. 229-246, 2017, [Online]. Available: http://almaiyyah.iainpare.ac.id/index.php/diktum/article/view/438/334. 
[5] Tjutjup Purwoko, "Analysis of the Factors Causing the Existence of Street Children in the City of Balikpapan," J. Sociol., vol. 4, no. 1, pp. 13-25, 2013.

[6] SL de Moura, "The social construction of the street children: Configuration and implications," Br. J. Soc., vol. 32, no. 1, pp. 253-367., 2002.

[7] Yudit Oktaria Kristiani Pardede, "Self Concept of Street Children at Adolescent Age," J. Psychol., vol. 1, no. 2, pp. 146-151, 2008.

[8] Virgayani Fattah, "Human Rights As Jus Cogens And Its Relation To The Right To Education," J. Yuridika, vol. 32, no. 2, pp. 355-378, 2017.

[9] State Secretariat, "Law Number 26 of 2000 Concerning Human Rights Courts and Law Number 39 of 1999 Concerning Human Rights." 2000.

[10] Chandra Muzaffar, Human Rights in the New World Order Challenge the Global Domination of the West. Bandung: Mizan, 1995.

[11] Jawahir Thontowi, International Law in Indonesia (Dynamics and Its Implementation in Several Humanitarian Cases). Yogyakarta: Madyan Press, 2002.

[12] Barda Nawawi Arief, Several Aspects of Criminal Law Enforcement and Development Policy. Bandung: Citra Aditya Bakti, 1998.

[13] Aswanto, "The Philosophy of Human Rights and Its Enforcement in the Perspective of a State of Law, was conveyed at the Seminar / Outreach of Legal Skills to All South Sulawesi Police Legal Officers and Their Ranks with the Theme of Increasing Legal Professionalism for Members of the Police." 2018. 